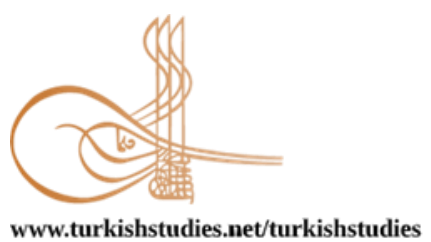

www.turkishstudies.net/turkishstudies
Turkish Studies

eISSN: $1308-2140$

Research Article / Araștırma Makalesi

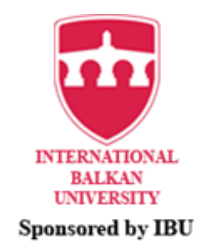

Sponsored by IBU

\title{
Covid-19 Salgınının Gıda ve İçecek Sektöründeki Şirketlerin Hisse Senedi Getiri ve Volatilitesine Etkisi
}

\author{
The Impact of Covid-19 Pandemic on Stock Returns and Volatility of Companies in Food and \\ Beverage Sector
}

\author{
Cüneyd Ebrar Levent ${ }^{*}$
}

\begin{abstract}
After the Covid-19 pandemic, there has been an extreme demand for food products all over the world. Whether this increase in demand in the sector is reflected in the financial markets is the main motivation of this study. In this context, the aim of this study is to determine the impact of the pandemic on stock returns and volatility of public companies in the food and beverage sector. The study mainly examined the Borsa Istanbul Food and Beverage Index (XGIDA) and the companies in this index. First, the performance of the XGIDA index was compared with the Borsa Istanbul reference indices using comparative analysis and trend analysis methods. Then, the food industry was examined on company basis. The return performances and volatility of the companies were analyzed in 10 portfolios created according to the company size, profitability and debt ratios. As a result of the trend analysis, it was determined that XGIDA index performed better than other indices during the research period. However, in the first phase of the pandemic, all indices, including the XGIDA index, were observed to have significant decrease. From these initial reactions, it can be interpreted that investors are exposed to the shock effect of the pandemic. Portfolio analysis findings strongly support the results obtained on the basis of indices. The results show that after the Covid-19 pandemic, all of the portfolios consisting of stocks of companies in the food industry offered higher return performance but higher volatility than reference indices. The results of the research that should be emphasized are that the portfolio consisting of companies with net losses had a return of $60.26 \%$ and the portfolio consisting of companies with very high debt ratio has a return of $82.68 \%$. The study provides important evidence in the context of behavioral finance in terms of revealing the reactions of investors in a crisis environment.
\end{abstract}

Structured Abstract: Covid-19 (novel coronavirus), which first appeared in the Wuhan city of China in the last days of 2019, spread around the world in a short time. As of the end of May 2020, the total number of cases worldwide is $6,255,136$ and the number of virus-related deaths is 375.277 , and the pandemic has spread to over 200 countries (Worldometers, 2020). Due to the rapid spread of the epidemic and the exponential increase of virus-related deaths, many countries around the world have brought unprecedented restrictions, including closing the borders and declaring the curfew.

As a result of these prohibitions, worldwide production slowed down and economies came to a standstill during the time the restrictions were imposed. The effects of the pandemic on the real sector were also reflected in the financial markets, and serious shocks and fluctuations occurred in the foreign exchange,

\footnotetext{
* Dr. Öğr. Üyesi, İstanbul Aydın Üniversitesi, Anadolu Bil Meslek Yüksekokulu, Muhasebe ve Vergi Uygulamaları Asst. Prof. Dr., Istanbul Aydin University, Anadolu Bil Vocational School, Accounting and Tax Practices ORCID 0000-0003-1494-3029

cuneydebrarlevent@gmail.com

Cite as/ Atıf: Levent, C. E. (2020). Covid-19 Salgınının gıda ve içecek sektöründeki şirketlerin hisse senedi getiri ve volatilitesine etkisi. Turkish Studies, 15(6), 721-737. https://dx.doi.org/10.7827/TurkishStudies.44417

Received/Geliş: 22 June/Haziran 2020

Accepted/Kabul: 15 October/Ekim 2020

Copyright $(\mathrm{C}$ MDE, Turkey
} 
commodity, stocks and debt instruments markets. Stock markets in Turkey were also significantly affected by this pandemic, with the BIST 100 index falling more than $30 \%$ in two months. However, the pandemic has also created opportunities for some sectors in the short term. The food industry has become one of the sectors with the potential to turn this crisis into an opportunity. Because immediately after Covid-19 started to spread, there was an explosion in demand for food products all over the world. Whether this increase in demand in the sector is reflected in the financial markets is the main motivation of this study. In this context, the aim of this study is to determine the impact of the pandemic on stock returns and volatility of public companies in the food and beverage sector.

The literature on the impact of the Covid-19 pandemic on financial markets is very recent and evolving. In this respect, this study is aimed to contribute to the literature. Another contribution of the study is that it examines the impact of return and volatility not only on the basis of index, but also on the basis of both company and portfolio. In this context, this research is the first empirical study in Turkey to examine the impact of the pandemic on the stocks of companies in the food sector and the reaction of investors after the pandemic. Thus, the study is expected to shed light on future research.

In this study, mainly Borsa İstanbul Food and Beverage Index (XGIDA) and all companies in this index (22 companies) were examined. The research consists of several parts. First, the return performances of the BIST Food and Beverage Index (XGIDA) and the various indices of Borsa Istanbul (XU100, XUSIN and XUTUM) were compared. Performance analysis is carried out in three periods. After this analysis, trend analysis was carried out to demonstrate the trend of the XGIDA index and reference indices on a daily basis.

Then, the food industry was examined on a company basis. The return performances and volatility of the companies were analyzed in 10 portfolios created according to the company size, profitability and debt ratios. While creating these portfolios, each company was given equal weight. In portfolio analyzes, the periodic return, average daily return and average volatility of each portfolio are analyzed. The periodic return was determined as the return performance between 10.01.2020 and 29.05.2020, and the average daily return and average volatility were determined by calculating the daily averages in this period. In the volatility calculation, the method proposed by Parkinson (1980) which is currently used in determining the daily, hourly and intraday volatility of stock prices was preferred.

In the last part of the research, it was investigated whether the performance of the portfolio consisting of companies in the food and beverage sector was statistically different in terms of returns and volatility from Borsa İstanbul reference indices (XU100, XUSIN and XUTUM).

As a result of the trend analysis, it was determined that XGIDA index performed better than other indices during the research period. However, in the first phase of the outbreak, all indices, including the XGIDA index, were observed to have significant decrease. These initial reactions can be interpreted as investors were exposed to the shock effect of the pandemic.

Portfolio analysis findings strongly support the results obtained on the basis of index. The results show that after the Covid-19 outbreak, all of the portfolios consisting of stocks of companies in the food industry offered higher return performance but higher volatility than reference indices. Equal-weighted portfolio consisting of all companies in the food index yielded a 55.91\% return between 10 January 2020 and 29 May 2020. However, the XU100 index fell $11.08 \%$ in the same period. 7 of the 10 portfolios that were created achieved over $50 \%$ performance in the five-month period, and 2 of them achieved over $80 \%$ performance. The findings also presents very surprising results. The results of the research that should be emphasized are that the portfolio consisting of companies with net losses in 2019 yielded a return of $60.26 \%$ and the portfolio consisting of companies with very high debt ratio was $82.68 \%$.

In the context of behavioral finance, the study provides important evidence for investors to react in a crisis environment. According to the results, it can be said that while considering the excessive demand for food products, investors are not taking the financial structure of the companies into account while trying to take advantage of the short term increase in the market.

It has been only five and a half months since Covid-19's first appearance in the world, and there are significant uncertainties regarding both the spread of the outbreak, the vaccine studies and the response of the financial markets. Future researchers are suggested to address the issue in a wider time dimension and to cover more countries.

Turkish Studies, 15(6) 
Keywords: Finance, Financial markets, Covid-19, Behavioral finance, Volatility, Portfolio, stock return

Öz: Covid-19 salgını sonrası tüm dünyada gıda ürünlerine yönelik aşırı bir talep meydana gelmiştir. Sektörde yaşanan bu talep artışının finansal piyasalara yansıyıp yansımadığı konusu, bu çalışmanın ana motivasyonunu oluşturmuştur. Bu bağlamda, bu çalışmanın amacı salgının gıda ve içecek sektöründeki halka açık şirketlerin hisse senedi getiri ve volatilitesine etkisini belirlemektir. Çalışmada esas olarak Borsa İstanbul Gıda ve İçecek Endeksi (XGIDA) ve bu endekste yer alan şirketler incelenmiştir. İlk olarak XGIDA endeksinin performansı, Borsa İstanbul referans endeksleri ile karşılaştırmalı analiz ve trend analizi yöntemleri kullanılarak incelenmiştir. Daha sonra gıda sektörü şirketler bazında ele alınmıştır. Şirketlerin getiri performansları ve volatiliteleri, şirket büyüklüğü, kârlılık ve borç oranlarına göre oluşturulan 10 portföyde analiz edilmiştir. Trend analizi sonucunda XGIDA endeksinin araştırma döneminde, diğer endekslere göre daha iyi performans gösterdiği belirlenmiştir. Bununla birlikte salgının ilk evresinde XGIDA endeksi de dahil, tüm endekslerde önemli değer kayıplarının olduğu görülmüştir. Bu ilk tepkiler, yatırımcıların salgının şok etkisine maruz kaldığı şeklinde yorumlanabilir. Portföy analiz bulguları ise endeks bazında elde edilen sonuçları daha kuvvetli desteklemektedir. Sonuçlar, Covid-19 salgını sonrası gıda sektöründeki şirketlerin hisse senetlerinden meydana gelen portföylerin tamamının referans endekslerden daha fazla getiri performansı ancak daha yüksek volatilite sunduğunu göstermektedir. Net zarar elde eden şirketlerden oluşan portföyün $\% 60,26$, borç oranı çok yüksek şirketlerden oluşan portföyün ise \%82,68 getiri sağlaması, araştırmanın üzerinde durulması gereken sonuçlarındandır. Çalışma, davranışsal finans bağlamında, kriz ortamında yatırımcıların tepkilerini göstermesi açısından önemli kanıtlar sunmaktadır.

Anahtar Kelimeler: Finans, Finansal piyasalar, Covid-19, Davranışsal finans, Volatilite, Portföy, Hisse senedi getirisi

\section{Giriş}

İlk kez 2019 yılı Aralık ayında Çin'in Wuhan şehrinde ortaya çıkan Covid-19 (Koronavirüs), kısa bir süre içinde önce Çin'e ardından tüm dünyaya yayılmıştır. Virüs kaynaklı ilk ölümün 9 Ocak 2020'de gerçekleştiği 11 Ocak 2020'de resmi olarak duyrulmuştur. Dünyada onaylanmış Covid-19 vaka sayısı Ocak sonunda 10.000'i, Şubat sonunda 80.000'i aşmıştır. Dünya Sağlık Örgütü ise 11 Mart 2020 tarihinde hastalığın pandemi olarak kabul edildiğini açıklamıştır (WHO, 2020). Mayıs sonu itibarıyla ise dünya genelindeki toplam vaka sayısı 6.255.136, virüs kaynaklı ölüm sayısı ise 375.277 olup, salgın 200’ün üzerindeki ülkeye yayılmış durumdadır (Worldometers, 2020).

Salgının başlarında, Covid-19'un SARS ve MERS salgınları gibi belli bölgelerle sınırlı kalacağ1 düşünülmekteydi. Fakat ilerleyen tarihlerle salgının sadece az gelişmiş veya gelişmekte olan ülkeleri değil, bütün ülkeleri etkisi altına aldığ1 görülmüştür (Bingül vd.,2020). Salgının hızlı yayılımı ve virüs kaynaklı ölümlerin katlanarak artması, ülkeleri ciddi tedbirler almaya itmiştir. Özellikle Şubat ayından başlayarak virüsün yayılımını kontrol etmek için neredeyse tüm dünyada, sınırların kapatılması, sokağa çıkma yasağının ilan edilmesi başta olmak üzere daha önce eşi benzeri görülmeyen kısıtlamalar hayata geçirilmiştir.

Uygulanan bu tedbirler sonucunda dünya genelinde üretim yavaşlamış, ülke ekonomileri kısıtlamaların uygulandığı süre içinde durma noktasına gelmiştir. Üretimin durma noktasına gelmesi, enerjiye olan ihtiyacın azalması, tüketimin gıdaya ve sağlığa yönelmesine neden olmuştur (Nakiboğlu ve Işık, 2020). Türkiye dahil birçok ülkede ulaştırma, turizm, konaklama, restoran, alışveriş merkezleri, kişisel bakım hizmetleri ve eğlence gibi sektörlerin faaliyetleri tamamen veya büyük ölçüde durdurulmuş, diğer sektörlerin çoğunda da faaliyetler yavaşlamıştır. Yavaşlama, geçmişteki bazı krizlerden farklı olarak sadece arz tarafinda değil talep tarafinda da yaşanmıştır. Salgının ekonomiye daha yıkıcı etki yapmaması için birçok ülke, sektörlere, şirketlere, çalışanlara ve tüm vatandaşlarına yönelik kurtarma, destek ve yardım paketleri açıklamıştır. 
Salgının reel sektöre etkileri, finansal piyasalara da yansımış, döviz, emtia, hisse senetleri ve borçlanma araçları piyasalarında ciddi şoklar ve dalgalanmalar meydana gelmiştir. Salgının çıkış yeri olan Çin'de Shanghai Composite Index, 22 Ocak 2020 - 3 Şubat 2020 tarihleri arasında \%10'dan fazla değer kaybetmiştir. Daha sonraki haftalarda endeks kısa süre içinde önce \%10'un üzerinde yükselmiş, ardından tekrar \%15'lere yaklaşan düşüş yaşamıştır (Marketwatch, 2020).

ABD'de Dow Jones Endeksinde ise salgının bu ülke için de tehdit olacağının algılanmasının ardından, bir ay içerisinde \%35'e varan kayıp gerçekleşmiştir (Bloomberg, 2020). Gelişmiş ülkeler ve Avrupa hisse senetleri piyasalarının da ABD ile korelasyon içinde hareket ettiği gözlenmiştir. Kriz ortamlarında yatırım için güvenli bir liman (safe haven) olması beklenen altında ise tahmin edilen aşırı yükseliş gerçekleşmemiş, hatta krizin Batı piyasaları için en kritik günlerinde (6 - 18 Mart aras1) ons bazında \%12'lik ani düşüş yaşanmıştır. Bu dönemde en şaşırtıcı olan ise, Haziran 2020 vadeli WTI ham petrol fiyatlarının sıfırın altına yaklaşık -38 USD seviyesine inmesi olmuştur (Forbes, 2020).

Türkiye'deki hisse senedi piyasaları da bu salgından önemli ölçüde etkilenmiş, 21 Ocak 2020'de 123.556 seviyesinde olan BİST 100 endeksi (XU100), iki ay içinde \%30'dan fazla değer kaybederek 23 Mart'ta 84.246 seviyesine kadar inmiştir. Bu tarihten sonra ise endeks aşırı volatil bir yapıya bürünmüştür. Düzenleyici kuruluş, açığa satış yasağı ve hisse senetlerinin gün içi tavan ve taban oranlarında değişiklikler yapılması gibi bir dizi tedbirler almıştır. Gerek Türkiye gerekse dünya hisse senetleri piyasalarında bu tarihten sonra önemli yükselişler yaşansa da, geleceğe yönelik belirsizlik devam etmektedir.

Reel ekonominin bu durumdan nasıl etkileneceği, bunun da finansal piyasalara nasıl yansıyacağı ise salgının nasıl seyredeceğine bağlıdır. Salgının GSYİH'ya etkisi ile ilgili dünyada farklı senaryolar tartışılmaktadır. Bu konuda yapılan bir araştırmada, salgının 2020 yılında kontrol edilmesi durumda, global ölçekte GSYİH'nın "V" şekli çizerek 2021'de en alt seviyeye ineceği, toparlanmanın ise en iyi ihtimalle 2022'de olacağı belirtilmektedir (EY, 2020). Aynı araştırmada ikinci senaryoda salgının küresel olarak kontrol edildiği ancak bölgesel şekilde tekrarlanması durumunda GSYİH'nın ardışı "U" 'lar çizmesi beklenmektedir. En kötü senaryoda ise önlemlerin salgını kontrol edemeyeceği, sadece etkisinin azaltacağı varsayılmaktadır. Bu senaryoda aşının 2021'de bulunma ihtimalinde bile GSYİH'nın "L" formunda 2022'ye kadar azalacağı ve bu bozulmanın kalıcı olacağı belirtilmektedir.

Covid-19 pandemisinin geçmişteki diğer salgınlara göre daha hızlı yayılması, finans ve ticaret piyasalarını daha yoğun etkilemesi; teknolojinin etkisiyle küreselleşmenin bir sonucu olarak düşünülebilir (Gülhan, 2020). Bununla birlikte, salgın beraberinde bazı sektörler için kısa dönemde firsatlar da sunmaktadır. Bu sektörlerin başında gıda sektörü gelmektedir. Türkiye'de gıda sektöründe ihracat rakamı, salgının dünyada hız kazanmaya başladığ 2020 yılı Mart ayında bir önceki yılın aynı dönemine göre \%15,5 artmıştır (TGDF, 2020). İhracattaki bu talep aynı ayda iç pazara da yansımıştır. Covid-19 hastalığının pandemi olarak kabul edilmesinden ve salgının Türkiye'yi de etkileyeceği anlaşıldıktan sonra Türkiye'de gıda ürünlerine yönelik aşırı talep yaşanmıştır. Özellikle ilk haftalarda marketlere akın eden insan görüntüleri, boşalan market rafları ve bu konu ile haberler; yazılı, görsel ve dijital medyada yer almıştır. Tüketicilerin bir kısmında stoklama eğiliminin artması, dünyadaki duruma paralel bir şekilde Türkiye'de de gerçekleşmiştir. Sektörde yaşanan bu hareketliliğin finansal piyasalara yansıyıp yansımadığı konusu, bu çalışmanın ana motivasyonunu oluşturmuştur.

Bu bağlamda, bu çalışma Covid-19 salgınının Borsa İstanbul'da (BİST) işlem gören gıda ve içecek sektöründeki şirketlerin hisse senedi getiri ve volatilitelerine etkisini analiz etmeyi amaçlamaktadır. Çalışmada BİST Gıda ve İçecek Endeksinde (XGIDA) işlem gören 22 şirket incelenmiş olup, araştırma 10 Ocak 2020 - 29 Mayıs 2020 arasındaki dönemi kapsamaktadır. Araştırmada ilk olarak XGIDA’nın, BİST 100 Endeksi, BISST Sınai Endeksi ve BİST Tüm Endeksi 
ile dönemsel getiri performans karşılaştırma analizi ve trend analizi yapılmaktadır. Daha sonra gida ve içecek sektörü endeks bazında değil şirketler bazında incelenmektedir. Bu bağlamda şirketler, büyüklük, kârlılık ve borç oranlarına göre gruplandırılmakta, buna dayanarak 10 farklı portföy oluşturulmaktadır. Bu portföylerin her birinin dönemsel ve günlük ortalama getiri ile ortalama volatiliteleri analiz edilmektedir. Araştırmanın son kısmında ise gıda ve içecek sektöründeki şirketlerden oluşan portföyün performansının, Borsa İstanbul referans endeksleri ile ve gida ve içecek sektörünün de içinde bulunduğu BİST Sınai Endeksi ile getiri ve volatilite bağlamında istatistiksel farklılığı olup olmadığı araştırılmaktadır.

Covid-19 salgınının finansal piyasalara etkisi ile ilgili literatür yeni oluşmaktadır. Bu açıdan bu çalışmanın literatüre katkı sağlaması hedeflenmektedir. Çalışmanın diğer bir özelliği ise getiri ve volatilite bazlı etkiyi sadece endeks bazında değil, hem şirket hem portföy bazlı da incelemesidir. Bu bağlamda, bu çalışma Türkiye'de salgının gıda sektöründeki şirketlerin hisse senetlerine etkisini ve yatırımcıların salgın sonrası verdikleri tepkiyi inceleyen ilk analitik araştırma olup, çalışmanın gelecekte bu konuda çalışacak araştırmalara da 1şık tutması beklenmektedir.

Çalışmanın giriş bölümünü takip eden bir sonraki bölümünde Covid-19 salgını sonrasında yapılan çalışmaların anlatıldığı literatür incelemesi bölümü yer almaktadır. Üçüncü bölümde araştırmanın veri ve yöntemi, dördüncü bölümde ise araştırma bulgularına yer verilmektedir. Son bölümde ise araştırma sonuçları tartışılmakta ve öneriler sunulmaktadır.

\section{Literatür Taraması}

Covid-19 salgını sonrasında finansal piyasalardaki ani düşüş ve dalgalanmalar, kriz olarak adlandırılan bu durumun 2008 küresel finansal krizi ile karşılaştırılmasına neden olmuştur (Auger, 2020; Gunay, 2020; Strauss-Kahn, 2020). Ancak önceki finansal krizlerin aksine, mevcut krizin arkasındaki temel dinamikler hiç olmadığı kadar karmaşıktır (Ji vd., 2020). Bu son derece bulaşıcı virüsü kontrol altına almak için dünyadaki birçok ülke, şehirlerin kilitlenmesi ve sınırların kapatılması da dahil olmak üzere, ekonomiyi durma noktasına getiren kapsamlı önlemler almıştır.

Covid-19 virüsünün ilk olarak Çin'de görülmesi nedeniyle literatürde finansal piyasalara yönelik ilk araştırmalar, virüsün Çin piyasasına etkileri üzerine yapılımıştır. Corbet vd. (2020) Covid19 salgının piyasalara bulaşma etkisini incelediği araştırmasında, Çin'in sadece fiziksel değil finansal bulaşmanın da merkezi olduğunu belirtmiştir. Yazarlar, salgın öncesinde Şanghay Borsası ile Dow Jones, WTI, altın ve bitcoin arasındaki korelasyonların, salgın sonrasında önemli oranda arttığını saptamışlardır. Çin'e yönelik diğer bir çalışmada Al-Awadhi vd. (2020) panel veri analizini yöntem olarak kullandıkları araştırmalarında hem doğrulanmış vakalardaki hem de Covid-19'un neden olduğu toplam ölüm vakalarındaki günlük büyümenin, tüm şirketlerin hisse senedi getirileri üzerinde önemli olumsuz etkilere sebep olduğunu saptamışlardır.

Salgının yayılması ile birlikte Çin piyasasının diğer piyasalarla karşılaştıııldığ yoğunlaştığı görülmektedir. Bu çalışmaların birinde Sansa (2020), 1 Mart 2020 ile 25 Mart 2020 tarihleri arasında Çin ve ABD'de salgının etkilerini incelemiştir. Araştırma bulguları, onaylanmış Covid-19 vakaları ile Çin ve ABD'de bu tarihler arasında tüm finansal piyasalar (Şangay Borsası ve New York Borsası) arasında pozitif anlamlı bir ilişki olduğunu ortaya koymaktadır. Başka bir çalışmada ise Ali vd. (2020) aralarında Çin'in de bulunduğu piyasalarda endeks getirileri ve volatilitelerdeki değişimi "epidemi” ve "pandemi” olarak iki süreçte ele almıştır. Yazarlar, salgının merkez üssü olan Çin'in bu özelliğini kaybetmesiyle bu ülkedeki piyasaların nispeten istikrara kavuştuğunu, salgının yeni merkezlerindeki piyasaların ise serbest düşüşe (freefall) geçtiğini vurgulamışlardır.

Covid-19 kaynaklı günlük vaka ve ölüm sayılarının ülkeler bazında yayımlanması ile birlikte virüsün piyasalara etkisinin bu parametrelerle ilişkisine yönelik çalışmalar artmıştır. Ashraf (2020), 22 Ocak 2020 - 17 Nisan 2020 döneminde 64 ülkeden günlük COVID-19 kaynaklı vaka ve 
ölümler ile borsa getirileri kullanarak, vaka ve ölüm sayıları ile borsa getirileri arasında ilişkiyi araştırmıştır. Yazarlar, borsaların onaylanmış COVID-19 vakalarındaki büyümeye olumsuz tepki verdiğini saptamışlardır. Araştırmada ayrıca, borsaların, teyit edilen vaka sayısındaki büyümeye (ölüm sayısındaki artışa göre) daha proaktif bir şekilde tepki verdiğini tespit edilmiştir.

Zeren ve Hızarcı (2020) ise Covid-19 salgınının seçilmiş ülkelerdeki borsalar üzerine etkilerini araştırmıştır. Sonuçlar, araştırma kapsamında ülkelerin tamamında toplam ölüm sayıları ile borsaların uzun vadede birlikte hareket ettiğini, vaka sayıları ile ise SSE (Çin), KOSPI (Güney Kore) ve IBEX35 (İspanya) endekslerinin eşbütünleşme ilişkisi içerisinde olduğunu göstermektedir. Diğer bir çalışmada ise Şenol ve Zeren (2020) Covid-19 salgının küresel piyasalar üzerindeki etkisini araştırmıştır. 21 Ocak 2020 ve 7 Nisan 2020 tarihleri arasında yapılan çalışmada, borsalar ile Covid19 arasında uzun dönemli bir ilişki olduğu tespit edilmiştir.

Volatilite, finansal piyasaların işleyişi için çok önemlidir. Volatilite, finansal yatırımları çevreleyen bir finansal risk, kriz veya belirsizlik barometresi gibi davranır ve bu nedenle fon yöneticilerine, yatırımcılara ve şirketler yöneticilerine önemli ipuçları sunar (Zaremba vd., 2020). $\mathrm{Bu}$ çerçevede salgının piyasalardaki volatiliteye etkisi de giderek artan bir araştırma konusu olmaktadır. Zhang vd. (2020) aralarında ABD, Çin, Fransa, İspanya ve İngilitere'nin de bulunduğu 12 ülkeyi kapsayan araştırmalarında Şubat ve Mart sonu onaylanmış vaka sayıları ile piyasalardaki volatiliteleri karşılaştırılmıştır. Vaka sayılarının aşırı artış gösterdiği ülkelerdeki piyasalarda volatilitelerin üç kata kadar arttığı saptanmıştır.

Türkiye’ye salgın diğer ülkelere göre nispeten geç gelmiştir. Finansal piyasalara etkisi de bu doğrultuda gerçekleşmiştir. Bu yüzden Türkiye piyasası ile ilgili ulusal literatür yeni oluşmaktadır. Bu konuda yayınlanmış az sayıdaki çalışmalardan birinde Kılıç (2020), Covid-19 salgınının BİST sektör endekslerinin getirileri üzerine etkisini incelemiştir. Olay çalışması yönteminin uygulandığ1 çalışmada sektörel endeks bazında en yüksek negatif getirilerin tekstil ve turizm sektöründe, en yüksek pozitif getirinin ise ticaret sektöründe gerçekleştiği saptanmıştır.

Türkiye'de Covid-19 salgınının gıda ve içecek endeksine olan muhtemel etkisine odaklanan bir çalışmaya ise rastlanmamıştır. Bununla birlikte yapılan makro düzeydeki çalışmalar, gıda ve içecek sektörünün, salgından diğer sektörlere göre daha az etkileneceği yönünde bulgular sunmaktadır. Bu çerçevede Özatay ve Sak (2020) Covid-19 sürecinin bir değil, birden fazla çeyrekte devam etmesi halinde, salgının Türkiye'de sektör bazında GSYH'ya etkilerini incelemiş, başta eğlence-kültür, lokanta, oteller ve ulaştırma sektörü olmak üzere birçok sektörde daralmanın yaşanacağını vurgulamıştır. Yazarlar haberleşme ile özel tüketim içindeki "konut, su, elektrik, gaz ve diğer yakıtlar" grubunda ise bir değişimin yaşanmayacağını belirtmişlerdir. Çalışmada gıda sektörünün krizden en az etkilenecek sektörlerden biri olarak yaklaşık \% 5 daralacağı öngörülmüştür.

Diğer bir araştırmada ise EY (2020), 46 ülke, 14 sektör ve 2.900'den fazla yönetici kapsayan araştırmalarında virüsün şirketlere etkisini araştırmıştır. Buna göre yöneticilerin \%95'i Covid-19 salgınının şirketlerin hem kârlılıklarını hem de kâr marjlarını azaltacağını belirtmiş̧lerdir. Araştırmada şirketlerin \%72'sinin kalıcı bir dönüşüm için çalışmalara başladıkları, \%52'sinin ise mevcut tedarik zincirinin değişmesi yönünde hazırlıklar yaptıkları saptanmıştır. Araştırmada ayrıca müşteri harcamalarının ertelenebilme olanağının olmadığı sektörlerin, pandemiden daha az etkileneceği vurgulanmış, bu sektörlerin başında gıda perakendeciliği ve sigorta sektörünün geldiği belirtilmiştir.

Literatürdeki mevcut bütün bu çalışmalar incelendiğinde, Covid-19'un gıda sektörüne etkisinin genellikle endeks boyutunda veya makro düzeyde ele alındığı görülmektedir. Gerek ulusal gerekse uluslararası literatürde pandeminin borsalarda işlem gören gıda şirketlerinin hisse senedi getiri ve volatilitelerine etkisini, hem şirket hem portföy bazında inceleyen bir çalışmaya ise rastlanmamıştır. Bu açıdan, bu çalışmanın literatürdeki önemli bir boşluğu doldurması hedeflenmektedir. 


\section{Araştırma Veri ve Yöntemi}

Bu araştırmada, Covid-19 salgınının Borsa İstanbul'da (BİST) işlem gören gıda ve içecek sektöründeki şirketlerin hisse senedi getiri ve volatilitelerine etkisinin analiz edilmesi amaçlanmıştır. Gıda sektörü, diğer sektörlere göre salgından en az etkilenen sektörlerin başında gelmektedir. Sektördeki firmaların bir kısmı artan müşteri talebini karşılayabilmek için, diğer sektörlerin aksine faaliyetlerini genişletmişlerdir. Bu bağlamda, araştırma reel bazda gözlenen bu artışın, yatırımcıların salgına karşı verdikleri tepkiyi de dikkate alarak, gıda sektöründeki halka açık şirketlerin piyasa değerine etkisini belirlemeyi de hedeflemektedir.

Araştırma BİST Gıda ve İçecek Endeksi'nde yer alan 22 şirketi kapsamaktadır ve bu şirketlerin listesi Tablo 1'de verilmiştir.

Tablo 1: Araştırma Kapsamındaki Şirketler

\begin{tabular}{|c|c|c|}
\hline & BİST Kodu & Şirket Ünvanı \\
\hline 1 & AEFES & ANADOLU EFES BİRACILIK VE MALT SANAYİI A.Ş. \\
\hline 2 & AVOD & A.V.O.D. KURUTULMUŞ GIDA VE TARIM ÜRÜNLERİ A.Ş. \\
\hline 3 & BANVT & BANVIT BANDIRMA VİTAMİNLİ YEM SANAYİ̇ A.Ş. \\
\hline 4 & CCOLA & COCA-COLA İÇECEK A.Ş. \\
\hline 5 & ERSU & ERSU MEYVE VE GIDA SANAYİ A.Ş. \\
\hline 6 & KENT & KENT GIDA MADDELERİ SANAYIII VE TİCARET A.Ş. \\
\hline 7 & KERVT & KEREVITAŞ GIDA SANAYİ VE TİCARET A.Ş. \\
\hline 8 & KNFRT & KONFRUT GIDA SANAYİ VE TİCARET A.Ş. \\
\hline 9 & KRSTL & KRİSTAL KOLA VE MEŞRUBAT SANAYİ TİCARET A.Ş. \\
\hline 10 & MERKO & MERKO GIDA SANAYİ VE TİCARET A.Ş. \\
\hline 11 & OYLUM & OYLUM SINAİ YATIRIMLAR A.Ş. \\
\hline 12 & PENGD & PENGUEN GIDA SANAYİ A.Ş. \\
\hline 13 & PETUN & PINAR ENTEGRE ET VE UN SANAYİI A.Ş. \\
\hline 14 & PINSU & PINAR SU VE İÇECEK SANAYİ VE TICARET A.Ş. \\
\hline 15 & PNSUT & PINAR SÜT MAMULLERİ SANAYIII A.Ş. \\
\hline 16 & TATGD & TAT GIDA SANAYİ A.Ş. \\
\hline 17 & TKURU & TAZE KURU GIDA SANAYİ VE TİCARET A.Ş. \\
\hline 18 & TUKAS & TUKAŞ GIDA SANAYİ VE TİCARET A.Ş. \\
\hline 19 & TBORG & TÜRK TUBORG BİRA VE MALT SANAYIII A.Ş. \\
\hline 20 & ULUUN & ULUSOY UN SANAYİ VE TİCARET A.Ş. \\
\hline 21 & ULKER & ÜLKER BİSKÜVİ SANAYİ A.Ş. \\
\hline 22 & VANGD & VANET GIDA SANAYİ İÇ VE DIŞ TİCARET A.Ş. \\
\hline
\end{tabular}

Kaynak: (KAP, 2020)

Araştırma zaman boyutu olarak 10 Ocak 2020 - 29 Mayıs 2020 arasındaki dönemi kapsamaktadır. Başlangıç olarak 10 Ocak 2020 tarihinin seçilmesinin nedeni, bu tarihte Türkiye'de COVID-19 hastalığ 1 ile mücadele için Sağlık Bakanlığ 1 tarafından Koronavirüs Bilim Kurulunun oluşturulmuş olmasıdır (Sağlık Bakanlığı, 2020). Bu yüzden resmi olarak farkındalığın oluştuğu ve harekete geçildiği bu tarih araştırmanın da başlangıç tarihi olarak tercih edilmiştir.

Araştırma birkaç kısımdan oluşmaktadır. Her kısımda farklı analizler uygulanmaktadır. Bu analizler ile veri ve yöntemleri aşağıda açıklanmaktadır: 
İlk olarak BİST Gıda ve İçecek Endeksinin (XGIDA), Borsa İstanbul referans endeksi olarak kabul edilen BİST 100 Endeksi (XU100), BİST Sınai Endeksi (XUSIN) ve BİST Tüm Endeksi (XUTUM) ile dönemsel getiri performans karşılaştırma analizi yapılmaktadır. Bu analiz üç ayrı dönemde ele alınarak gerçekleştirilmektedir:

1) 10 Ocak 2020 - 29 Mayıs 2020 dönemi

2) 10 Ocak 2020 - 17 Mart 2020 dönemi (17 Mart 2020 tarihi Türkiye'de COVID-19'dan ilk ölümün Sağlık Bakanlığı tarafından duyrulduğu tarihtir)

3) 17 Mart 2020 - 29 Mayıs 2020 dönemi

Dönemsel analizden sonra XGIDA endeksinin ve yukarıda belirtilen endekslerin günlük bazda trendini ortaya koymak için trend analizi yapılmaktadır.

Bir sonraki kısımda ise gıda ve içecek sektörü, endeks bazında değil şirket bazında incelenmektedir. Araştırma kapsamında yer alan 22 şirket, şirketlerin 31.12.2019 mali tablolarında yer alan bilgilere ve hesaplanan oranlara göre gruplandırılmaktadır. Buna dayanarak 10 farklı portföy oluşturulmuştur. $\mathrm{Bu}$ portföyler ve hangi kriterlere göre bu portföylerin oluşturulduğu Tablo 2'de sunulmaktadir.

Tablo 2: Oluşturulan Portföylerin Özellikleri

\begin{tabular}{|c|c|c|c|}
\hline Portföy Adı & Şirket Sayısı & Kriter & Açıklama \\
\hline Portföy 1 & 7 & Toplam Varlıklar & Varlık sıralamasına göre büyük şirketler \\
\hline Portföy 2 & 8 & Toplam Varlıklar & Varlık sıralamasına göre orta büyüklükteki şirketler \\
\hline Portföy 3 & 7 & Toplam Varlıklar & Varlık sıralamasına göre küçük şirketler \\
\hline Portföy 4 & 7 & ROA & ROA $\geq \% 5$ olan şirketler \\
\hline Portföy 5 & 8 & ROA & ROA $>0$ ve $\mathrm{ROA}<\% 5$ olan şirketler \\
\hline Portföy 6 & 7 & ROA & ROA $<0$ (dönem net kârı negatif) olan şirketler \\
\hline Portföy 7 & 10 & Borç Oranı & Borç oranı $<\% 50$ olan şirketler \\
\hline Portföy 8 & 6 & Borç Oranı & $\begin{array}{l}\text { Borç oran } 1 \geq \% 50 \text { ve borç oran } 1<\% 70 \text { olan } \\
\text { şirketler }\end{array}$ \\
\hline Portföy 9 & 6 & Borç Oranı & Borç oran $1 \geq \% 70$ olan şirketler \\
\hline Portföy TÜM & 22 & --- & Gıda ve içecek sektöründeki tüm şirketler \\
\hline
\end{tabular}

1,2 ve 3 numaralı portföyler şirket büyüklüklerine göre oluşturulmuştur. Literatürde şirket büyüklüğünü temsilen toplam varlıklar kaleminin kullanıldığı görülmektedir (Carter \& Simkins, 2003; Dang vd., 2018; Triyono vd., 2019). Bu yüzden bu çalışmada da şirket büyüklüğü kriteri olarak şirketlerin 31.12.2019 bilançosundaki toplam varlıklar değeri esas alınmıştır. Gıda sektöründeki 22 şirket toplam varlıklarına göre sıralanmış, en büyük 7 şirket Portföy 1'i, daha sonraki 8 şirket Portföy 2'yi ve toplam varlıklar1 en düşük 7 şirket de Portföy 3 'ü oluşturmuştur.

4,5 ve 6 numaralı portföyler ise şirketlerin kârl1l1klarına göre düzenlenmiştir. Kârlılığ temsilen ise aktif kârlılık oranı (ROA) seçilmiştir. Aktif kârlılık oranı \% 5'den büyük olan 7 şirket Portföy 4'ü, 0 ile \% 5 arasında olan 8 şirket Portföy 5'i oluşturmuştur. ROA oranı negatif olan, zarar eden şirketler ise Portföy 6'yı meydana getirmiştir. Literatürde aktif kârlılık oranının belirlenmesine yönelik farklı yöntemler bulunmaktadır. Bu çalışmada ROA hesaplamasında Chen vd. (2005) tarafindan da kullanılan (1) numaralı denklem tercih edilmektedir: 


$$
\text { ROA }=\frac{\text { Net Kâr }}{\text { Toplam Varlıklar }}
$$

7, 8 ve 9 numaralı portföylerde ise borç oranı kriter olarak alınmıştır. Borç oranı $\%$ 50'den düşük olan şirketler Portföy 7'yi, \% 50 - \% 70 arasındaki şirketler Portföy 8'i, \% 70'in üzerinde olan şirketler ise Portföy 9'u oluşturmuştur. Borç oranı hesaplamasında (2) numaralı denklem kullanılmaktadır:

$$
\text { Borç oranı }=\frac{\text { Toplam Borçlar }}{\text { Toplam Kaynaklar }}
$$

Portföy TÜM olarak ifade edilen portföy ise gıda sektöründeki 22 şirketten oluşan portföyü temsil etmektedir. Referans olarak tüm analizlerde tabloların sonuna eklenmiştir. Toplam 10 portföy oluşturulurken her şirkete eşit ağırlık verilmiştir.

Portföy analizlerinde, her portföyün dönemsel getirisi, ortalama günlük getirisi ve ortalama volatilitesi analiz edilmektedir. Dönemsel getiri yukarıda açıklanan gerekçeler çerçevesinde 10.01.2020 ile 29.05.2020 arasındaki getiri performansı şeklinde, ortalama günlük getiri ve ortalama volatilite ise bu dönem içindeki günlük ortalamalar hesaplanarak belirlenmiştir. Volatilite hesabında Parkinson (1980) tarafından önerilen ve günümüzde halen hisse senedi fiyatlarının günlük, saatlik ve dakikalık volatilitelerinin belirlenmesinde kullanılan yöntem tercih edilmiştir. Bu araştırmada, Parkinson metodu, literatürde Chan vd. (2004) tarafından hesaplanan şekliyle kullanılmıştır (3):

$$
V_{t}^{\mathrm{P}}=0.361\left[\log \left(\frac{\operatorname{High}_{t}}{\operatorname{Low}_{t}}\right)\right]^{2}
$$

(3) numaralı denklemde;

$\mathrm{V}_{\mathrm{t}}^{\mathrm{P}}$ : Parkinson volatilitesi

0.361: Volatilite sabiti $=1 /(4 \ln 2)$

High $_{\mathrm{t}}$ : hisse senedinin gün içi ulaştığı en yüksek değeri

Low $_{t}$ : hisse senedinin gün içi ulaştığı en düşük değeri ifade etmektedir.

Araştırmanın son bölümünde ise gıda ve içecek sektöründeki şirketlerden oluşan portföyün performansının, Borsa İstanbul referans endeksleri (XU100 ve XUTUM) ve gida ve içecek sektörünün de içinde bulunduğu BİST Sınai Endeksi (XUSIN) ile getiri ve volatilite bağlamında istatistiksel farklılığı olup olmadığı araştırılmaktadır. Buna yönelik 6 hipotez oluşturulmuştur:

$\mathrm{H} 1_{0}$ : Gıda ve içecek sektöründeki şirketlerden oluşan portföyün getirisi ile XU100 endeksinin getirisi arasında istatistiksel olarak anlamlı bir farklılık bulunmamaktadır.

$\mathrm{H} 2_{0}$ : G1da ve içecek sektöründeki şirketlerden oluşan portföyün getirisi ile XUSIN endeksinin getirisi arasında istatistiksel olarak anlamlı bir farklılık bulunmamaktadır.

H3 : Gıda ve içecek sektöründeki şirketlerden oluşan portföyün getirisi ile XUTUM endeksinin getirisi arasında istatistiksel olarak anlamlı bir farklılık bulunmamaktadır.

$\mathrm{H} 4_{0}$ : G1da ve içecek sektöründeki şirketlerden oluşan portföyün volatilitesi ile XU100 endeksinin volatilitesi arasında istatistiksel olarak anlamlı bir farklılık bulunmamaktadır.

$\mathrm{H} 5_{0}$ : G1da ve içecek sektöründeki şirketlerden oluşan portföyün volatilitesi ile XUSIN endeksinin volatilitesi arasında istatistiksel olarak anlamlı bir farklılık bulunmamaktadır.

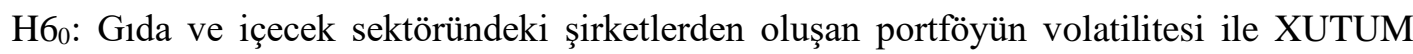
endeksinin volatilitesi arasında istatistiksel olarak anlamlı bir farklılık bulunmamaktadır. 
Alternatif hipotezler ise "istatistiksel olarak anlamlı fark vardır" şeklinde kurulmuştur. Analizlerde $t$ testi uygulanmaktadır. Bu araştırmada kullanılan tüm veriler Borsa İstanbul (BISST) ve Kamuyu Aydınlatma Platformu (KAP) gibi halka açık kaynaklardan elde edilmiştir. Şirketlerden veri talep edilmemiştir. Bu yüzden Etik Kurul Raporu'na ihtiyaç bulunmamaktadır. Analizlerde Excel ve Stata 14 programları kullanılmıştır.

\section{Araştırma Bulguları}

Araştırma kapsamında yer alan gıda ve içecek sektöründeki şirketlerin büyüklüklerine göre dağglımı Tablo 3'de verilmiştir. Büyüklük kriteri olarak şirketlerin 31.12.2019 itibarıyla toplam varlıkları esas alınmıştır. Tablo 3'e göre 3 şirket 10 milyar TL'nin üzerinde büyüklüğe sahiptir. Toplam varlıkları 1-10 milyar TL arasında olan 5, 100 milyon TL ile 1 milyar TL arasinda olan 9 şirket bulunmaktadır. 100 milyon TL'nin altında toplam varlığa sahip şirket sayısı ise 5'dir.

Tablo 3: Gıda ve İçecek Sektöründeki Şirketlerin Toplam Varlıklarına Göre Dağılımı

\begin{tabular}{lrr}
\hline Toplam Varlıklar & Frekans & \% \\
\hline 100 milyon TL'den küçük & 5 & $22,73 \%$ \\
100 milyon TL - 1 milyar TL arası & 9 & $40,91 \%$ \\
1 milyar TL - 10 milyar TL arası & 5 & $22,73 \%$ \\
10 milyar TL'den büyük & 3 & $13,64 \%$ \\
\hline Toplam & $\mathbf{2 2}$ & $\mathbf{1 0 0 , 0 0 \%}$ \\
\hline
\end{tabular}

Şirketlerin aktif kârlılık oranlarına (ROA) göre dağılımı ile Tablo 4'de sunulmaktadır. Buna göre şirketlerin \% 31,82'sinin ROA oranları negatif olup bu, söz konusu şirketlerin 2019 yılını net zararla kapadıklarını göstermektedir. \% 5'in altında kâr eden şirketlerin oranı ise \% 36,36'dır. Bu iki sonuç birlikte ele alınırsa; sektördeki şirketlerin üçte ikisinin ROA oranı olarak \% 5 'in üzerine çıkamadığını göstermesi açısından önemlidir. Şirketlerin \% 22,73'ünün aktif kârlılık oranı \% 5 ile yaklaşık \%10 arasındadır. ROA olarak \%10'un üzerinde olan şirket sayısı ise yalnızca 2'dir.

Tablo 4: Gıda ve İçecek Sektöründeki Şirketlerin Aktif Kârlılık Oranlarına Göre Dağılımı

\begin{tabular}{lrr}
\hline Aktif Kârlılık Oranı (ROA) & Frekans & \% \\
\hline ROA $<0$ & 7 & $31,82 \%$ \\
$\% 0-\% 4,99$ arası & 8 & $36,36 \%$ \\
$\% 5-\% 9,99$ arası & 5 & $22,73 \%$ \\
\% 10'dan büyük & 2 & $9,09 \%$ \\
\hline Toplam & $\mathbf{2 2}$ & $\mathbf{1 0 0 , 0 0 \%}$
\end{tabular}

Tablo 5'de ise gıda ve içecek sektöründeki şirketlerin borçlulukları açısından analiz sonuçlarına yer verilmektedir. Şirketlerin $\% 45,45$ 'inin borç oranı $\% 50$ 'nin altındadır. Sektördeki şirketlerin yaklaşık \%27'si ise 2019 yılını \% 70'in üzerinde borç oranıyla kapatmıştır.

Tablo 5: Gıda ve İçecek Sektöründeki Şirketlerin Borç Oranlarına Göre Dağılımı

\begin{tabular}{lrr}
\hline Borç Oranı & Frekans & \% \\
\hline$\% 50$ 'den küçük & 10 & $45,45 \%$ \\
$\% 50$ - \% 69,99 arası & 6 & $27,27 \%$ \\
$\%$ 70'den büyük & 6 & $27,27 \%$ \\
\hline Toplam & $\mathbf{2 2}$ & $\mathbf{1 0 0 , 0 0 \%}$ \\
\hline
\end{tabular}


Şekil 1'deki grafikte gıda ve içecek sektörünün 2020 yılı performansı endeks bazında diğer referans endekslerle karşılaştırmalı olarak verilmiştir. Burada trend analizi yöntemi kullanılmış, 2020 yılının ilk iş günü olan 2 Ocak 2020 baz gün olarak belirlenmiş, bu tarihte endekslerin değeri 100 olarak kabul edilmiştir. 6 aylık dönemin (102 işlem günü) neredeyse tamamında BİST Gıda ve İçecek Endeksinin (XGIDA) performansının diğer endekslerden daha fazla olduğu görülmektedir. İncelenen dört endeks de Şubat ayının ilk yarısında tepe noktalarına ulaşmış, ayın ikinci yarısında ise düşüsşe geçmiştir. Endekslerde (XGIDA endeksi dahil) keskin düşüş ise Mart ayının ikinci haftasının başında gerçekleşmiş, endeksler 10 gün içinde \% 20'ye yaklaşan değer kayıpları yaşamışlardır. 17 Mart 2020 tarihinden itibaren COVID-19 pandemisinde yaşanan olumsuz gelişmelere karşın endekslerde, dip seviyelerine göre önemli yükselişler olmuştur. Gıda endeksinde ise bu yükseliş diğer endekslere göre daha yüksek oranda yaşanmıștır. Bu sonuç, yatırımcıların gıda sektöründeki hisse senetlerine daha fazla yöneldiğini göstermektedir. Dönemsel getirilere ilişkin analiz sonuçları Tablo 6'da verilmektedir.

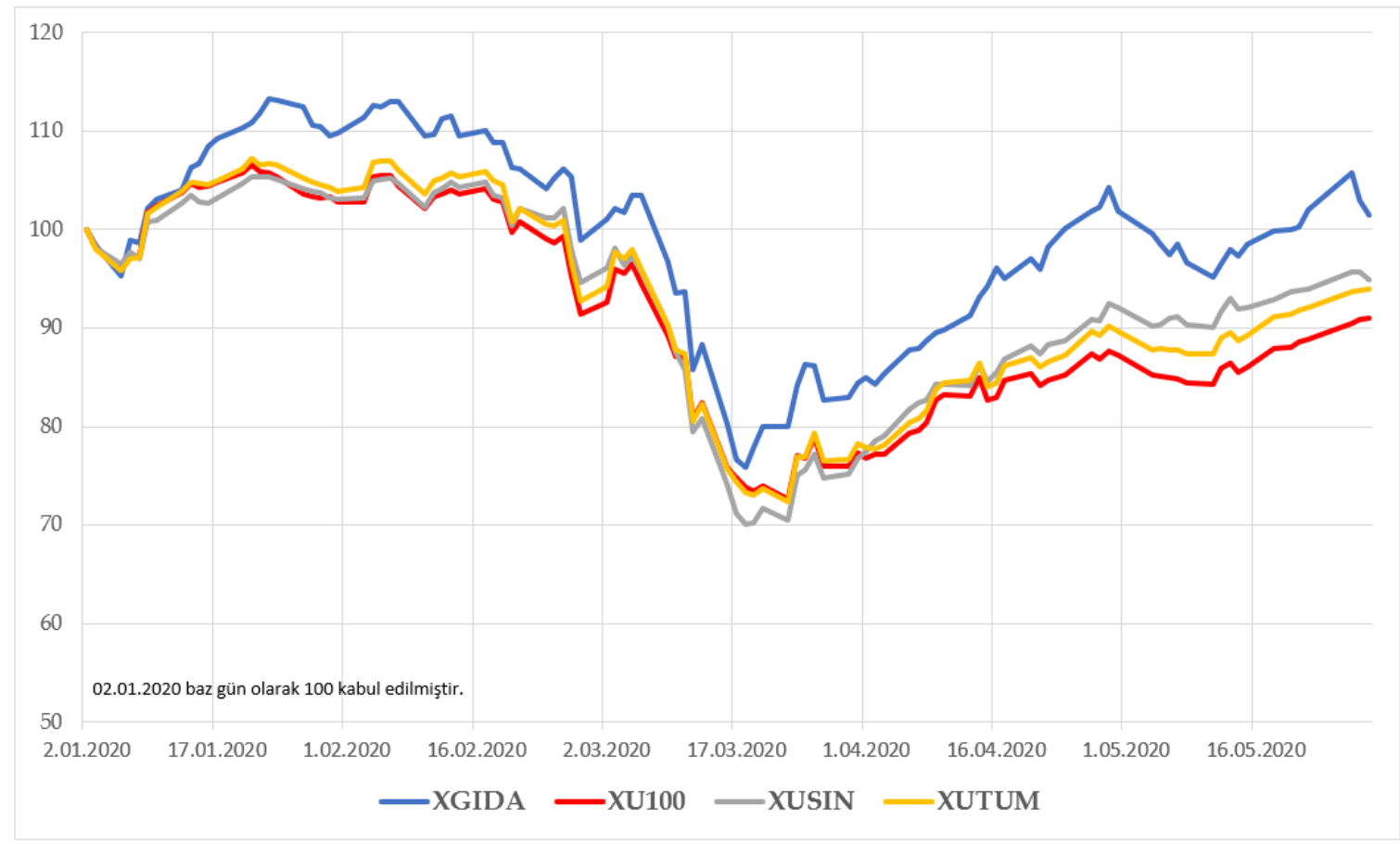

Şekil 1: XGIDA ve Diğer Endekslerin 2020 Y1lı Trend Analizi

Tablo 6'daki sonuçlar hem 10 Ocak - 29 Mayıs dönemin tamamında, hem de incelenen iki dönemde XGIDA endeksi performansının XU100 ve XUTUM endekslerinden fazla olduğunu göstermektedir. 10 Ocak - 17 Mart döneminde XGIDA endeksinde \%25,67 düşüş yaşanırken, bir sonraki dönemde ise \%32,46'lık bir artış gerçekleşmiştir. Dönemin tamamını ise gıda endeksi \%1,54'lük kayıpla tamamlamıştır. Bu kayıp, XU100, XUSIN ve XUTUM endekslerinden daha az olsa da, bu durum bile gıda sektörünün gerçek performansını yansıtmamaktadır. Çünkü endeks hesaplamasında piyasa değeri ve işlem hacmi yüksek olan AEFES, CCOLA ve ULKER gibi hisse senetlerinin ağırlığı fazladır, bu hisse senetleri sektörün çok altında performans sergilemişlerdir. Tablo 7, Tablo 8 ve Tablo 9'da sunulduğu gibi eşit ağırlıklandırma yapıldığında endeksin performansının \%55,91 olduğu görülmektedir. 
Tablo 6: BİST Gıda ve İçecek Endeksi (XGIDA) Performansının Diğer Endekslerle Karşılaştırılması

\begin{tabular}{|c|c|c|c|c|c|c|c|c|c|}
\hline \multirow[b]{2}{*}{ Endeksler } & \multicolumn{3}{|c|}{ 10.01.2020 - 29.05.2020 Dönemi } & \multicolumn{3}{|c|}{ 10.01.2020 - 17.03.2020 Dönemi } & \multicolumn{3}{|c|}{ 17.03.2020 - 29.05.2020 Dönemi } \\
\hline & 10.01 .2020 & 29.05.2020 & $\begin{array}{c}\text { Değişim } \\
\%\end{array}$ & 10.01.2020 & 17.03.2020 & $\begin{array}{c}\text { Değişim } \\
\%\end{array}$ & 17.03.2020 & 29.05.2020 & $\begin{array}{c}\text { Değişim } \\
\%\end{array}$ \\
\hline XGIDA & 145.957 & 143.707 & $-1,54 \%$ & 145.957 & 108.495 & $-25,67 \%$ & 108.495 & 143.707 & $32,46 \%$ \\
\hline XU100 & 118.664 & 105.520 & $-11,08 \%$ & 118.664 & 86.778 & $-26,87 \%$ & 86.778 & 105.520 & $21,60 \%$ \\
\hline XUSIN & 142.332 & 133.711 & $-6,06 \%$ & 142.332 & 100.385 & $-29,47 \%$ & 100.385 & 133.711 & $33,20 \%$ \\
\hline XUTUM & 123.755 & 113.791 & $-8,05 \%$ & 123.755 & 90.033 & $-27,25 \%$ & 90.033 & 113.791 & $26,39 \%$ \\
\hline
\end{tabular}

Tablo 7'de gıda ve içecek sektöründeki şirketlerin büyüklüklerine oluşturan portföylere ait sonuçlar sunulmaktadır. Bir önceki bölümde belirtildiği gibi büyüklük kriteri olarak şirketlerin 31.12.2019 bilançolarında toplam varlıklar tutarı seçilmiştir. Büyük şirketlerden oluşan Portföy 1, $\% 14,42$ ile en düşük dönemsel getiriyi sağlamaktadır. Risk-getiri teorilerine uygun olarak en düşük volatilite de bu portföyde bulunmaktadır. Orta büyüklükteki şirketlerden oluşan Portföy 2 ise hem en fazla getiriyi $(\% 90,58)$ sunmakta, hem de en yüksek riske sahip olan portföy olarak göze çarpmaktadır. Sektörde toplam varlıklar açından en küçük 7 şirketten oluşan Portföy 3 ise \%57,79'luk getiri ile, tüm şirketlerden oluşan Portföy TÜM'den $(\% 55,91)$ daha fazla dönemsel getiri sağlamaktadır.

Tablo 7: Şirket Büyüklüklerine Göre Oluşturulan Portföylerin Getiri ve Volatilite Analiz Sonuçları

\begin{tabular}{lcrrr}
\hline Portföyler & N & Dönemsel Getiri $\left(^{*}\right)$ & Ort. Günlük Getiri & Ort.Volatilite \\
\hline Portföy 1 & 7 & $14,42 \%$ & $0,192 \%$ & $2,70 \mathrm{E}-04$ \\
Portföy 2 & 8 & $90,58 \%$ & $0,732 \%$ & $4,82 \mathrm{E}-04$ \\
Portföy 3 & 7 & $57,79 \%$ & $0,594 \%$ & $4,44 \mathrm{E}-04$ \\
Portföy TÜM & 22 & $55,91 \%$ & $0,516 \%$ & $4,02 \mathrm{E}-04$ \\
\hline
\end{tabular}

(*) Dönemsel getiri 10.01.2020 - 29.05.2020 arasındaki dönemi ifade etmektedir.

Aktif kârlılık oranlarına (ROA) göre oluşturulan portföylerin getiri ve volatilitelerine ait analiz sonuçları ise Tablo 8'de verilmektedir. 2019 gelir tablosuna göre en fazla kârlılık oranına sahip şirketlerden oluşan Portföy 4, sektör ortalamasının da altında \% 45,03'lük dönemsel getiri sağlamıştır. Portföy 5 en riskli portföy olmasına karşın, en yüksek getiri elde edilen portföy olmuştur. Araştırmanın en çarpıcı sonuçlarından birisi ile Portföy 6'da elde edilmiştir. Mali tablolarında net dönem zararı belirten 7 şirketten meydana gelen bu portföy, sektör ortalamasının üstünde ve Portföy 5 'e çok yakın bir dönemsel getiri sağlamıştır.

Tablo 8: ROA Oranlarına Göre Oluşturulan Portföylerin Getiri ve Volatilite Analiz Sonuçları

\begin{tabular}{lcrrr}
\hline Portföyler & N & Dönemsel Getiri (*) & Ort. Günlük Getiri & Ort.Volatilite \\
\hline Portföy 4 & 7 & $45,03 \%$ & $0,398 \%$ & $3,46 \mathrm{E}-04$ \\
Portföy 5 & 8 & $61,63 \%$ & $0,589 \%$ & $4,62 \mathrm{E}-04$ \\
Portföy 6 & 7 & $60,26 \%$ & $0,551 \%$ & $3,90 \mathrm{E}-04$ \\
Portföy TÜM & 22 & $55,91 \%$ & $0,516 \%$ & $4,02 \mathrm{E}-04$ \\
\hline
\end{tabular}

(*) Dönemsel getiri 10.01.2020 - 29.05.2020 arasındaki dönemi ifade etmektedir. 
Tablo 9'da ise portföyler şirketlerin borç oranlarına göre düzenlenmiştir. Borç oran1 \%50'nin altında olan şirketlerden oluşan Portföy 7, \%56,65 ile sektör ortalamasının biraz üzerinde getiri sağlamıştır. Ayrıca bu portföyün volatilitesi de sektör ortalamasından daha düşüktür. Borç oran $1 \% 50$ - \%70 arasındaki şirketlerden oluşan Portföy 8, sektör ortalamasının yarısı kadar getiri elde etmiştir. Tablo 8'deki sonuçlara benzer şekilde; borç oranı \%70'in üzerinde olan şirketlerden oluşan Portföy $9, \% 82,68$ ile en yüksek getiriyi sağlamıştır.

Tablo 9: Borç Oranlarına Göre Oluşturulan Portföylerin Getiri ve Volatilite Analiz Sonuçları

\begin{tabular}{lcrrr}
\hline Portföyler & N & Dönemsel Getiri (*) & Ort. Günlük Getiri & Ort.Volatilite \\
\hline Portföy 7 & 10 & $56,65 \%$ & $0,519 \%$ & $3,81 \mathrm{E}-04$ \\
Portföy 8 & 6 & $27,92 \%$ & $0,324 \%$ & $3,71 \mathrm{E}-04$ \\
Portföy 9 & 6 & $82,68 \%$ & $0,704 \%$ & $4,68 \mathrm{E}-04$ \\
Portföy TÜM & 22 & $55,91 \%$ & $0,516 \%$ & $4,02 \mathrm{E}-04$ \\
\hline
\end{tabular}

(*) Dönemsel getiri 10.01.2020 - 29.05.2020 arasındaki dönemi ifade etmektedir.

Tablo 7, Tablo 8 ve Tablo 9'da elde edilen tüm sonuçlar Şekil 2'deki saçılım grafiğinde (scatter plot) sunulmaktadır. Grafikte Borsa İstanbul'da referans endeksi olan XU100'ün, tüm şirketlerden oluşan XUTUM'ün ve imalat sanayi şirketlerden oluşan XUSIN'ın negatif performans gösterdiği görülmektedir. Bu endekslerin klasik risk-getiri teorileriyle tutarlı olarak volatiliteleri düşüktür. Buna karşın gıda sektöründeki şirketlerden oluşan portföylerin tamamı referans endekslerden fazla dönemsel getiri sağlamıştır. Üstelik oluşturulan 10 portföyün 7'si beş aylık dönemde \%50'nin, 2'si ise \%80'in üzerinde performans elde etmiştir. Ancak portföylerin tamamının endekslere göre çok riskli olduğunu da belirtmek gerekmektedir.

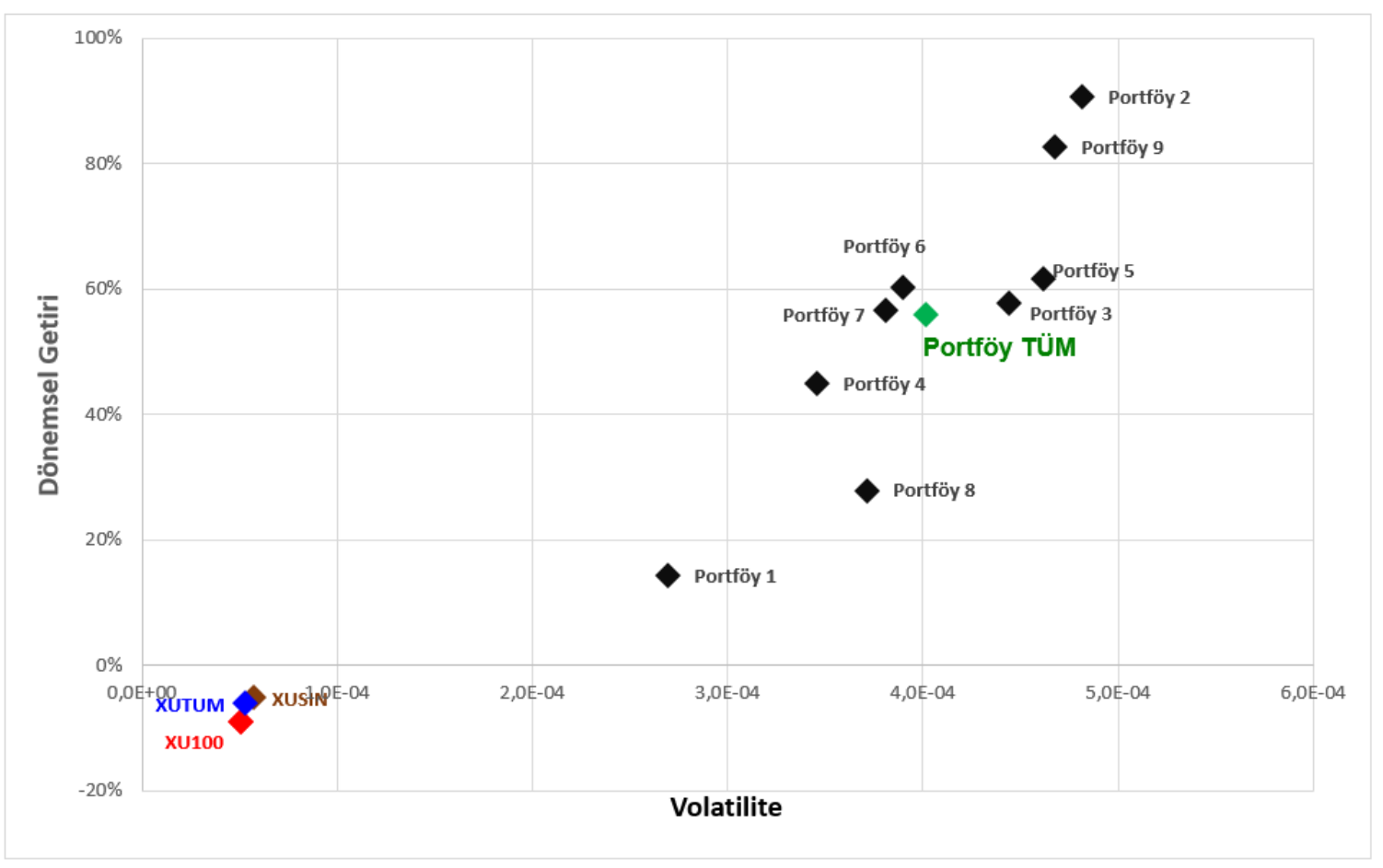

Şekil 2: Portföylerin ve Endekslerin Getiri - Volatilite Karşılaştırması 
Çalışmada son olarak gıda ve içecek sektöründeki şirketlerin tamamından oluşan portföyün getiri ve volatilitesi günlük olarak analiz edilmektedir. Tablo 10 'da verilen $t$ testi sonuçlarına göre gıda portföyünün günlük ortalama getirisi hem XU100 endeksinden hem de XUTUM ve XUSIN endekslerinden anlamlı bir şekilde farklıdır. $\mathrm{Bu}$, yukarıda dönemsel olarak verilen sonuçları doğrulamaktadır. Buna göre "g1da ve içecek sektöründeki şirketlerden oluşan portföyün getirisi ile XU100, XUSIN ve XUTUM endeksinin getirisi arasında istatistiksel olarak anlamlı bir farklılık bulunmamaktadır" şeklinde kurulan H1, H2 ve H3 hipotezleri reddedilmektedir.

Tablo 10: Günlük Getiri ve Volatilite Bazında Karşılaştırma Analizi Sonuçları

\begin{tabular}{lrrrr}
\hline & \multicolumn{2}{c}{ Ort. Günlük Getiri } & \multicolumn{2}{c}{ Ort. Günlük Volatilite } \\
\hline Karşılaştırma Endeksi & $\mathbf{t}$ istatistiği & $\mathbf{P}$ olasılık değeri & $\mathbf{t}$ istatistiği & P olasılık değeri \\
\hline XU100 & 1,88 & $0,0632^{*}$ & 8,71 & $0,0000^{* * *}$ \\
XUSIN & 1,71 & $0,0899^{*}$ & 8,54 & $0,0000^{* * *}$ \\
XUTUM & 1,77 & $0,0801^{*}$ & 8,66 & $0,0000^{* * *}$ \\
\hline
\end{tabular}

$*, * *, * * * \% 10, \% 5$ ve \% 1 düzeylerinde istatistiksel olarak anlamlı

Tablo 10'da ortaya çıkan diğer önemli sonuç ise, gıda ve içecek şirketlerden oluşan portföyün XU100, XUTUM ve XUSIN endekslerinden daha riskli olduğudur. Şekil 2'de dönemsel olarak sunulan grafikteki ortaya çıkan sonuç, günlük bazda $t$ istatistik ve $\mathrm{P}$ olasılık değerleri ile kanıtlanmaktadır. Buna göre "g1da ve içecek sektöründeki şirketlerden oluşan portföyün volatilitesi ile XU100, XUSIN ve XUTUM endeksinin volatilitesi arasında istatistiksel olarak anlamlı bir farklılık bulunmamaktadır" şeklinde kurulan H4, H5 ve H6 hipotezleri reddedilmektedir. P olasılık değerleri volatilitedeki istatistiksel farklılı̆gın getirideki farklılıktan çok daha anlamlı olduğunu ortaya koymaktadır.

\section{Sonuç, Tartışma ve Öneriler}

Bu çalışmanın amacı Covid-19 salgınının gıda ve içecek sektöründeki halka açık şirketlerin hisse senetlerine etkisini belirlemektir. Bu etki hem getiri hem de volatilite bazında araştırılmıştır. Araştırmada Borsa İstanbul'da Gıda ve İçecek Endeksinde (XGIDA) işlem gören 22 şirket incelenmiş olup zaman boyutu olarak 10 Ocak 2020 - 29 Mayıs 2020 arasındaki dönemi kapsamaktadır.

Araştırmada ilk olarak BİST Gıda ve İçecek Endeksinin, BİST 100 Endeksi, BİST Sınai Endeksi ve BIST Tüm Endeksi ile dönemsel getiri performans karşılaştırma analizi ve trend analizi yapılmıştır. $\mathrm{Bu}$ analizlerin sonucunda XGIDA endeksinin araştırma döneminde, diğer endekslere göre daha iyi performans gösterdiği belirlenmiştir.

Ancak özellikle trend analizi sonuçları Türkiye'de hem ilk Covid-19 vakası görüldükten hem de hastalık kaynaklı ilk ölüm olayı resmi olarak duyrulduktan sonra endekslerin sert bir şekilde düştüğünü göstermektedir. Bu da yatırımcıların belirsizliğin maksimum olduğu noktada tepkisinin "endişe" olduğu ve ellerindeki hisse senetlerini daha fazla zarara uğramamak için sattığ 1 şeklinde yorumlanabilir. XGIDA endeksi bile bu sert düşüşe karşı koyamıştır. Bu, sektörlerin birbirlerinden farklı dinamikleri olsa da şoklara ve piyasa trendlerine aykırı hareket edemediğini göstermesi açısından önemlidir.

Araştırmada endekslerin durumu şok sonrasındaki dönem için de ayrıca ele alınmış, dip noktasını görüldükten sonra endekslerin toparlandıkları ortaya konulmuştur. Bu sonuç, yatırımcıların aşırı değer kaybeden hisse senetlerine değer artış kazancı sağlamak amacıyla talep etmeleri şeklinde yorumlanabilir. Gıda endeksinin bu dönemde diğer endekslerden ayrışarak, relatif olarak daha fazla 
getiri sağladığı belirlenmiştir. Üstelik bu durum, aşırı gıda talebinin azalmaya başladığı dönemde bile devam etmiştir.

Çalışmanın en önemli bölümünü, gıda ve içecek sektörünün endeks bazında değil şirketler bazında incelendiği araştırma oluşturmaktadır. Bu çerçevede şirketler, 2019 mali tabloları esas alınarak, büyüklük, kârlılık ve borçluluk durumlarına göre gruplandırılmış, buna dayanarak 10 farklı portföy oluşturulmuştur. Bu portföylerin her birinin dönemsel ve günlük ortalama getiri ile ortalama volatiliteleri belirlenmiştir. Sonuçlar, farklı kriterlere göre gıda sektöründeki şirketlerin hisse senetlerinden meydana gelen portföylerin tamamının XU100, XUTUM ve XUSIN'dan daha fazla getiri performansı sağladığını göstermektedir.

Üstelik oluşturulan 10 portföyün 7'si beş aylık dönemde \%50'nin, 2'si ise \%80'in üzerinde performans elde etmiştir. 2019 yılını zararla kapatan şirketlerden oluşan portföyün \%60,26, borç oranı çok yüksek şirketlerden oluşan portföyün ise $\% 82,68$ getiri sağlaması araştırmanın üzerinde durulması gereken sonuçlarındandır.

$\mathrm{Bu}$ çalışmanın sonuçlarından hareketle, yatırımcıların gıda ürünlerine olan aşırı talebi görerek, gıda sektöründeki hisse senetlerine talep gösterirken, şirketlerin mali yapılarını fazla dikkate almadıkları, piyasadaki kısa vadeli değer artış kazancından yararlanmaya çalıştıkları söylenebilir.

Buna karşın araştırmada portföylerin tamamının endekslere göre aşırı volatiliteye sahip olduğu hem dönemsel bazda hem de istatistiksel olarak günlük bazda da saptanmıştır. Elde edilen bütün bu sonuçlar, kriz ve pandemi gibi nedenlerden dolayı belirsizliğin yüksek olduğu dönemlerde; piyasayı oluşturan yatırımcıların günlük hatta gün içi meydana gelen gelişmelerden aşırı derecede etkilendikleri ve kararlarını buna göre verdikleri şeklinde yorumlanabilir.

Araştırma hem gida endeksinde hem de diğer endekslerde 17 Mart 2020 sonrasında yaşanan iki buçuk aylık dönemde \%20'yi aşan yükselişi ortaya koyması açısından da önemlidir. Üstelik bu yükseliş Türkiye'de günlük vaka sayıların dört basamaklı rakamlara ulaştığı, günlük vefat sayılarının yüzleri aştığ1 ve salgının gidişatı ile ilgili belirsizliğin en üst seviyede olduğu dönemde gerçekleşmiştir. Bu açıdan yatırımcılara, düzenleyici kuruluşlara ve araştırmacılara, bu çalışmanın sonuçlarını davranışsal finans bağlamında da değerlendirilmeleri önerilmektedir.

Covid-19 hastalığının pandemi olarak kabul edilmesinden ve salgının Türkiye'yi etkileyeceği anlaşıldıktan sonra tüketicilerde gıda ürünlerine aşırı talep olmuştur. Araştırma sonuçları bu talebin, gıda ve içecek sektöründeki şirketlerin hisse senetlerine de yansıdığını göstermektedir.

Bununla beraber, araştırma kapsamındaki 22 şirketin hisse senedinin 19'unda beş aylık dönemde dönemsel getiri elde edilmesine karşın, XGIDA endeksinin aynı dönemde \% 1,54 kayıp yaşadığı saptanmıştır. Bunun sebebi üç büyük şirketin endeksteki ağırlığının fazla olmasıdır. Araştırma, sektör endekslerinin, sektörün gerçek durumunu her zaman yansıtmayacağını göstermesi açısından da önemli bulgular ortaya koymaktadır. Finansal piyasalarda sektör performansının daha doğru yansıtılması açısından, düzenleyici kuruluşlara alternatif metodlarla hesaplanan sektör endeksleri üzerinde çalışmaları önerilmektedir.

Covid-19 salgınının gerek küresel gerekse bölgesel bazda nasıl bir seyir izleyeceği henüz bilinmemektedir. Salgının finansal piyasalara etkisi konusunda araştırmalar çok sınırlıdır. Bu araştırma Türkiye'de Covid-19 salgınının gıda sektöründeki şirketlerin hisse senetlerini etkisini inceleyen ilk çalışmadır. Bu açıdan araştırmanın yeni oluşmakta olan literatüre de katkı sağlaması hedeflenmektedir.

Araştırmanın yukarıda belirtilen katkıları yanında sınırlılıkları da bulunmaktadır. Salgının dünyada ilk ortaya çıkışından bu yana bir yıl bile geçmemiştir ve hem salgının yayılımı hem aşı çalışmaları hem de finansal piyasaların durumu ile ilgili önemli belirsizlikler bulunmaktadır. $\mathrm{Bu}$ 
yüzden araştırma beş aylık bir dönemi ele almıştır. Diğer bir sınırlılık ise araştırmanın sadece Türkiye'yi kapsamış olmasıdır. Gelecek araştırmacıların konuyu daha geniş zaman boyutunda ve daha fazla ülkeyi kapsayacak şekilde ele almaları önerilmektedir.

\section{Kaynakça}

Al-Awadhi, A., Alsaifi, K., Al-Awadhi, A., \& Alhammadi, S. (2020). Death and Contagious Infectious Diseases: Impact of the COVID-19 Virus on Stock Market Returns. Journal of Behavioral and Experimental Finance, 27, 1-5. https://doi.org/10.1016/j.jbef.2020.100326

Ali, M., Alam, N., \& Rizvi, S. (2020). Coronavirus (COVID-19) - An Epidemic or Pandemic for Financial Markets. Journal of Behavioral and Experimental Finance, 27, 1-6. https://doi.org/10.1016/j.jbef.2020.100341

Ashraf, B. (2020). Stock markets' reaction to COVID-19: Cases or fatalities? Research in International Business and Finance. https://doi.org/10.1016/j.ribaf.2020.101249

Auger, B. (2020). COVID-19 and the Global Financial Crisis: An Economic Comparison. https://www.cambridgetrust.com/insights/investing-economy/covid-19-and-the-globalfinancial-crisis-an-econom

Bingül, B.A., Türk, A., \& Ak, R. (2020). Covid-19 Bağlamında Tarihteki Büyük Salgınlar ve Ekonomik Sonuçları. Turkish Studies, 15(4), 189-200.

Bloomberg. (2020). Dow Jones Industrial Average. https://www.bloomberg.com/quote/INDU:IND

Carter, D., \& Simkins, B. (2003). Corporate Governance, Board Diversity, and Firm Value. The Financial Review, 38(1), 33-53. https://doi.org/10.1111/1540-6288.00034

Chan, K., Fung, H.-G., \& Leung, W. (2004). Daily volatility behavior in Chinese futures markets. Journal of International Financial Markets, Institutions and Money, 14(5), 491-505. https://doi.org/10.1016/j.intfin.2004.01.002

Chen, Z., Cheung, Y.-L., Stouraitis, A., \& Wong, A. (2005). Ownership concentration, firm performance, and dividend policy in Hong Kong. Pacific-Basin Finance Journal, 13(4), 431449. https://doi.org/10.1016/j.pacfin.2004.12.001

Corbet, S., Larkin, C., \& Lucey, B. (2020). The contagion effects of the COVID-19 pandemic: Evidence from gold and cryptocurrencies. Finance Research Letters. https://doi.org/10.1016/j.frl.2020.101554

Dang, C., Li, Z., \& Yang, C. (2018). Measuring firm size in empirical corporate finance. Journal of Banking \& Finance, 86, 159-176. https://doi.org/10.1016/j.jbankfin.2017.09.006

EY. (2020). COVID-19 Etki Analizi: Küresel bulgular ve alinabilecek aksiyonlar. https://www.ey.com/Publication/vwLUAssets/covid-19-etki-analizi/\$File/covid-19_dunyave-turkiye-den-bulgular.pdf

Forbes. (2020). April 20: WTI At -\$37, Brent At \$26! What Happened? What Comes Next? The Stories That Will Be Told. https://www.forbes.com/sites/thebakersinstitute/2020/04/21/april20-wti-at37-brent-at-26-what-happened-what-comes-next-the-stories-that-will-be-told

Gunay, S. (2020). COVID-19 Pandemic Versus Global Financial Crisis: Evidence from Currency Market. https://papers.ssrn.com/sol3/papers.cfm?abstract_id=3584249

Gülhan, Ü. (2020). Covid-19 Pandemisine BIST 100 Reaksiyonu: Ekonometrik Bir Analiz. Turkish Studies, 15(4), 497-509. 
Ji, Q., Zhang, D., \& Zhao, Y. (2020). Searching for Safe-haven Assets during the COVID-19 Pandemic. International Review of Financial Analysis 71, https://doi.org/10.1016/j.irfa.2020.101526

KAP. (2020). Kaтиуи Aydınlatma Platformu. https://www.kap.org.tr/tr/Endeksler

Kılıç, Y. (2020). Borsa İstanbul'da COVID-19 (Koronavirüs) Etkisi. JOEEP: Journal of Emerging Economies and Policy, 5(1), 66-77.

Marketwatch.

Shanghai

Composite

Index. https://www.marketwatch.com/investing/index/shcomp?countrycode $=\mathrm{cn}$

Nakiboğlu, A., \& Işık, S. (2020). Kovid-19 Salgınının Ekonomi Üzerindeki Etkileri: Türkiye'de İşletme Sahipleri Üzerinde Bir Araştırma. Turkish Studies, 15(4), 765-789.

Özatay, F., \& Sak, G. (2020). Covid-19 Salgını Bir Değil, Bir Kaç Çeyrek Sürerse Ne Olur? http://www.tek.org.tr/files/disc/covid19_salgini_bir_degil_bir_kac_ceyrek_surerse_ne_olur _678.pdf

Parkinson, M. (1980). The Extreme Value Method for Estimating the Variance of the Rate of Return. The Journal of Business Vol. 53, No. 1, 61-65.

Sağlık Bakanlığı. (2020). 08.06.2020 tarihinde https://www.saglik.gov.tr/TR,11693/duyurular.html

Sansa, N. (2020). The Impact of the COVID-19 on the Financial Markets: Evidence from China and USA. https://papers.ssrn.com/sol3/papers.cfm?abstract_id=3562530

Strauss-Kahn, M.-O. (2020). Can we compare the COVID-19 and 2008 crises? https://www.atlanticcouncil.org/blogs/new-atlanticist/can-we-compare-the-covid-19-and2008-crises/

Şenol, Z., \& Zeren, F. (2020). Coronavirus (COVID-19) and Stock Markets: The Effects of the Pandemic on the Global Economy. Avrasya Sosyal ve Ekonomi Araştırmaları Dergisi, 7(4), $1-16$.

TGDF. (2020). Türkiye Gıda ve İçecek Sanayi Dernekleri Federasyonu. COVID-19 gıda ve içecek sektöründe dış ticareti nasıl etkiledi? : https://www.tgdf.org.tr/covid-19-gida-ve-iceceksektorunde-dis-ticareti-nasil-etkiledi/

Triyono, T., Kusumastuti, A., \& Palupi, I. (2019). The Influence of Profitability, Assets Structure, Firm Size, Business Risk, Sales Growth, and Dividend Policy on Capital Structure. Riset Akuntansi dan Keuangan Indonesia, 4(3), 101-111.

WHO. (2020). World Health Organization. WHO Director-General's opening remarks at the media briefing on COVID-19 - 11 March 2020: https://www.who.int/dg/speeches/detail/whodirector-general-s-opening-remarks-at-the-media-briefing-on-covid-19---11-march-2020

Worldometers. (2020). COVID-19 Coronavirus Pandemic. https://www.worldometers.info/coronavirus/

Zaremba, A., Kizys, R., Aharon, D., \& Demir, E. (2020). Infected Markets: Novel Coronavirus, Government Interventions, and Stock Return Volatility around the Globe. Finance Research Letters, https://doi.org/10.1016/j.frl.2020.101597

Zeren, F., \& Hizarc1, A. (2020). The Impact of COVID-19 Coronavirus on Stock Markets: Evidence From Selected Countries. Muhasebe ve Finans Incelemeleri Dergisi, 78-84.

Zhang, D., Hu, M., \& Ji, Q. (2020). Financial markets under the global pandemic of COVID-19. Finance Research Letters, https://doi.org/10.1016/j.frl.2020.101528 